\title{
Limited Resettlement and Ongoing Uncertainty: responses to and experiences of people seeking asylum in Australia and Indonesia
}

\author{
Caroline Fleay and Lisa Hartley \\ Curtin University
}

In the wake of the Coalition Government's narrow victory in the first Australian election since the adoption of policies known as Operation Sovereign Borders, this special edition of Cosmopolitan Civil Societies focuses its attention on the treatment of refugees and asylum seekers ${ }^{1}$. It explores some of the experiences of people both in Australia and Indonesia who are seeking a life of safety, as well as the responses of civil society groups and governments, following the commencement of policies that have vastly reduced the opportunities for refugee resettlement in Australia.

Operation Sovereign Borders was adopted by the Coalition Government upon its election in September 2013. It incorporates measures to intercept and deter the arrival of asylum seekers to Australia by boat. This has included turning back boats of asylum seekers, providing funding for joint operations with Indonesia, Malaysia and Sri Lanka to disrupt people smuggling activities, and reducing the number of resettlement places for refugees. In addition, the Coalition Government has sustained policies adopted by the previous Labor Government as well as implemented other punitive policies that impact people who have sought asylum in Australia. This includes denying the right to work to those who arrived by boat and were

\footnotetext{
${ }^{1}$ We use the term 'asylum seeker' here to refer to someone who arrives to a country seeking asylum but whose refugee status has not yet been finalised. We use the term 'refugee' as per the definition provided in the United Nations Convention Relating to the Status of Refugees - someone who is considered to be likely to face persecution should they return to their home country, on the grounds of their race, religion, nationality, membership of a particular social group or political opinion.

Caroline Fleay, Centre for Human Rights Education, Curtin University. Lisa Hartley, Centre for Human Rights

Education, Curtin University. Corresponding author: C.Fleay@curtin.edu.au

ISSN: 1837-5391; https://epress.lib.uts.edu.au/journals/index.php/mcs

CCS Journal is published under the auspices of UTSePress, Sydney, Australia

(C) 2016 Caroline Fleay, Lisa Hartley. This is an Open Access article distributed under the terms of the Creative Commons Attribution 4.0 Unported (CC BY 4.0) License

(https://creativecommons.org/licenses/by/4.0/), allowing third parties to copy and redistribute the material

in any medium or format and to remix, transform, and build upon the material for any purpose, even commercially, provided the original work is properly cited and states its license.
} 
released into the community, and the adoption of more restrictive refugee status determination procedures. These policies have drastically reduced the prospects for refugees and asylum seekers in the region to find resettlement in Australia at a time when people needing protection both globally and regionally has increased to the greatest number since World War II ${ }^{2}$.

The idea for the focus of the special edition emerged during a forum in Bangkok in 2014 organised by the Asia-Pacific Refugee Rights Network (APRRN). During one of the many presentations from local, regional and international refugee support agency participants about the situation for people seeking asylum in the region, it was noted that there was clearly an 'elephant in the room' - Australia. Repeatedly over those three days, accounts of the experiences of asylum seekers and refugees across Asia-Pacific included reference to the impacts of Australia's policies since the adoption of Operation Sovereign Borders in September 2013. A workshop co-organised by the authors the following year in Melbourne brought together representatives of some of these regional and domestic refugee support agencies, as well as academic researchers and people who had lived the experience of seeking asylum, to further explore the impacts of Australian policies. The findings of this workshop were that the actions of the Australian Government are having disturbing impacts on people seeking asylum both beyond our borders as well as within Australia ${ }^{3}$.

This special edition brings together the writings of researchers who are well placed to explore some of the impacts of Australian Government asylum seeker policies in the region, with a particular focus on Australia and Indonesia. Its contributions also include examples of how refugee communities, civil society groups and governments in the region are responding to the needs of increasing numbers of people requiring protection.

It commences with a focus on Asia Pacific Refugee Rights Network (APRRN), a regional civil society network that has become a key distributor of information on the experiences of refugees and asylum seekers in the region, including in relation to the impacts of Australian policies. Savitri Taylor outlines the development of APRRN as a regional body comprising

\footnotetext{
2 See UNHCR (2014) UNHCR Global Trends: Forced Displacement 2014. Available at: http://unhcr.org/556725e69.pdf

${ }^{3}$ This workshop was funded by the Academy of Social Sciences in Australia and the Australia-Asia-Pacific Institute at Curtin University. The full workshop report can be found here: http://www.assa.edu.au/events/workshop/126
} 
civil society organisations and individual members that advocates for the rights of people needing protection in the Asia-Pacific. Her exploration of the network highlights the considerable non-state efforts to work towards greater collaboration in the region in order to elevate the experiences of people from a refugee background in domestic, regional and international forums. Through drawing on her insider status as an APRRN member, Taylor reflects on the challenges facing the network seven years after it was first established in trying to achieve its mission. She concludes that while the network's membership has grown considerably over this time, its shared purposes have grown increasingly complex and this requires a high level of membership engagement and commitment.

Continuing a focus on the responses of those in the region to protracted periods of seeking asylum, Muzafar Ali, Linda Briskman and Lucy Fiske explore the experiences of a group of refugees in Indonesia in the wake of Australian Government policies that prevent their access to protection in Australia. Drawing on Ali's own experiences as a former refugee in Indonesia, and Briskman and Fiske's interviews with Ali and others in that country, they outline the extremely limited supports available for refugees and asylum seekers in Indonesia. They also outline an example of the agency and resilience of refugee communities in response to their protracted time in Indonesia and the uncertainty they face. This is done through an exploration of a school established by a group of refugees for asylum seeker and refugee children in West Java that illustrates a community-based approach to building stronger community connections and addressing their collective needs.

Graham Thom explores the experiences of another group of asylum seekers who have been denied the protection assistance of Australia and whose treatment in the region reflects the lack of regional and national protection frameworks. 1,800 people, many of them Rohingya who had fled Myanmar and Bangladesh, were left stranded in boats in the Andaman Sea in 2015 until they were rescued by Acehnese fisherman and granted temporary haven in Aceh, Indonesia. Drawing on his research with the Rohingya asylum seekers as part of an Amnesty International team, Thom highlights the uncertainties they face, as well as the local, Indonesian, regional and international responses to this group. This includes outlining that, despite the considerable international attention given to the desperate plight of this group, the Australian Government was reluctant to participate in regional responses and refused to offer resettlement assistance. 
The final two papers in this edition draw our attention to some of the impacts of Australia's policies on people seeking asylum within its own borders. Our contribution with Anita Lumbus reflects on recent statements in the public domain, including those of Coalition Government ministers, about the employment prospects of asylum seekers in Australia who arrived by boat. In the absence of evidence provided by media commentators and senior politicians that people who arrived to Australia by boat from 2007 to 2013 have limited employment prospects, and any research that specifically explores this, we review studies on refugees and employment to interrogate these claims. We conclude that while research highlights people from a refugee background may encounter difficulties accessing employment and are more likely to be employed in temporary and lower skilled occupations in the short term, over time refugees and their families significantly contribute to Australian communities and local economies. We also highlight that particular Australian policies, as well as negative public commentary in this area, are likely to be deepening the barriers that asylum seekers who arrived by boat may be experiencing to access employment.

Mary Anne Kenny, Nicholas Procter and Carol Grech also focus their attention on asylum seekers who came by boat to Australia, in particular those who arrived after 13 August 2012 and were eventually released from immigration detention into the Australian community. This group has lived in the community with minimal support. They were denied the right to work for the first 2-3 years following their release from immigration detention, and only given access to minimal financial assistance. While the processing of their refugee claims finally commenced in 2015, the Coalition Government has denied access to funded legal assistance for most people. Thus many are without help to navigate the highly complex protection process. Kenny, Procter and Grech explore these legal challenges and highlight how they compound the stress and trauma already experienced by people seeking asylum and the mental health implications of this.

The contributions in this special edition document some of the negative impacts of current Australian policies on those seeking safety both in the region and in Australia. They highlight the limited resettlement opportunities and the protracted uncertainty facing refugees and asylum seekers. But importantly, they also highlight examples of the agency and resilience of refugee communities. In the wake of the re-election of the Coalition Government in July 2016, ongoing attention to the experiences of refugees and asylum seekers within and beyond Australia’s borders continues to be needed. 